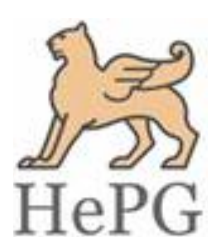

ISSN: 2348-1900

Plant Science Today

http://www.plantsciencetoday.online

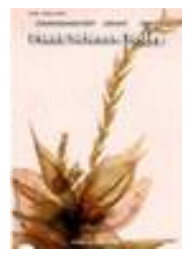

OPEN 2 ACCESS

Research Communication

\title{
The moss genus Regmatodon Brid. (Regmatodontaceae) - new to the Eastern Ghats
}

\author{
A E D Daniels, P M Biju \& V Asha \\ Bryology Laboratory, Department of Botany and Research Centre, Scott Christian College (Autonomous), Nagercoil 629 003, India
}

\section{Article history}

Received: 21 June 2019

Accepted: 31 July 2019

Published: 01 October 2019

\section{Publisher}

Horizon e-Publishing Group

\author{
*Correspondence \\ AE Dulip Daniels \\ \dulipdaniels@yahoo.co.uk
}

\begin{abstract}
Regmatodon orthostegius Mont. was earlier reported from Central India, the Himalaya, Northeast India and the Western Ghats in India. However, while collecting bryophytes from the Eastern Ghats, the authors came across a moss which was later identified as Regmatodon orthostegius which is a new distributional record for this genus as well. A detailed description with figure and photographic plates is provided.
\end{abstract}

Keywords: Eastern Ghats; Regmatodon orthostegius; Sherveroy Hills

Citation: Daniels AED, Biju PM, Asha V. The moss genus Regmatodon Brid. (Regmatodontaceae) - new to the Eastern Ghats. Plant Science Today 2019;6(4):439-441. https://doi.org/10.14719/pst.2019.6.4.597

\begin{abstract}
Copyright: (c) Daniels et al (2019). This is an open-access article distributed under the terms of the Creative Commons Attribution License, which permits unrestricted use, distribution, and reproduction in any medium, provided the original author and source are credited (https://creativecommons.org/licenses/by/4.0/).
\end{abstract}

Indexing: Plant Science Today is covered by Scopus,Web of Science, BIOSIS Previews, ESCI, CAS, AGRIS, CABI, Google Scholar, etc. Full list at http://www.plantsciencetoday.online

\section{Introduction}

Eakin (1) revised the moss genus Regmatodon Brid. on a world-wide basis and recognized only two valid species namely $R$. declinatus (Hook.) Brid. and $R$. othostegius Mont. (2). Regmatodon declinatus is an Asian species whereas $R$. othostegius is Pantropical and both the species occur in India (1, $3-5)$. However, only the latter has been reported from the Western Ghats in the Peninsula (1, 3-6). Surveys made on the bryoflora of Sherveroy Hills on the Eastern Ghats of Peninsular India led to the discovery of Regmatodon othostegius which is a new record for the Eastern Ghats. Incidentally, the genus is an addition to the moss flora of the Eastern Ghats (7-9). A key is provided for an easy segregation of the two known species.

\section{Key to the species}

1a. Seta rough; endostome smooth ... $\boldsymbol{R}$. declinatus

1b. Seta smooth; endostome coarsely papillose R. orthostegius

Regmatodon orthostegius Mont., Ann. Sci. Nat., Bot. sér. 2, 17: 248. 1842; Foreau, J. Madras Univ. 3: 122. 1930 \& J. Bombay Nat. Hist. Soc. 58: 37. 1961; Bruehl, Rec. Bot. Surv. India 13(1): 86. 1931; R.S. Chopra, Taxon. Indian Moss.: 413. 1975; Gangulee, Moss. E. India 3(7): 1563, f. 783. 1978; Vohra, Rec. Bot. Surv. India 23: 56. 1983; S.S. Kumar \& Maniselvan, Res. Bull. Panjab Univ., New Ser., Sci. 44: 101. 1994; D.A. Eakin \& B. Allen, Nova Hedwigia 69: 311. 1999; S. Kumar \& D.K. Singh, Bull. Bot. Surv. India 44: 132. 2002; J. Lal, Checklist Indian 

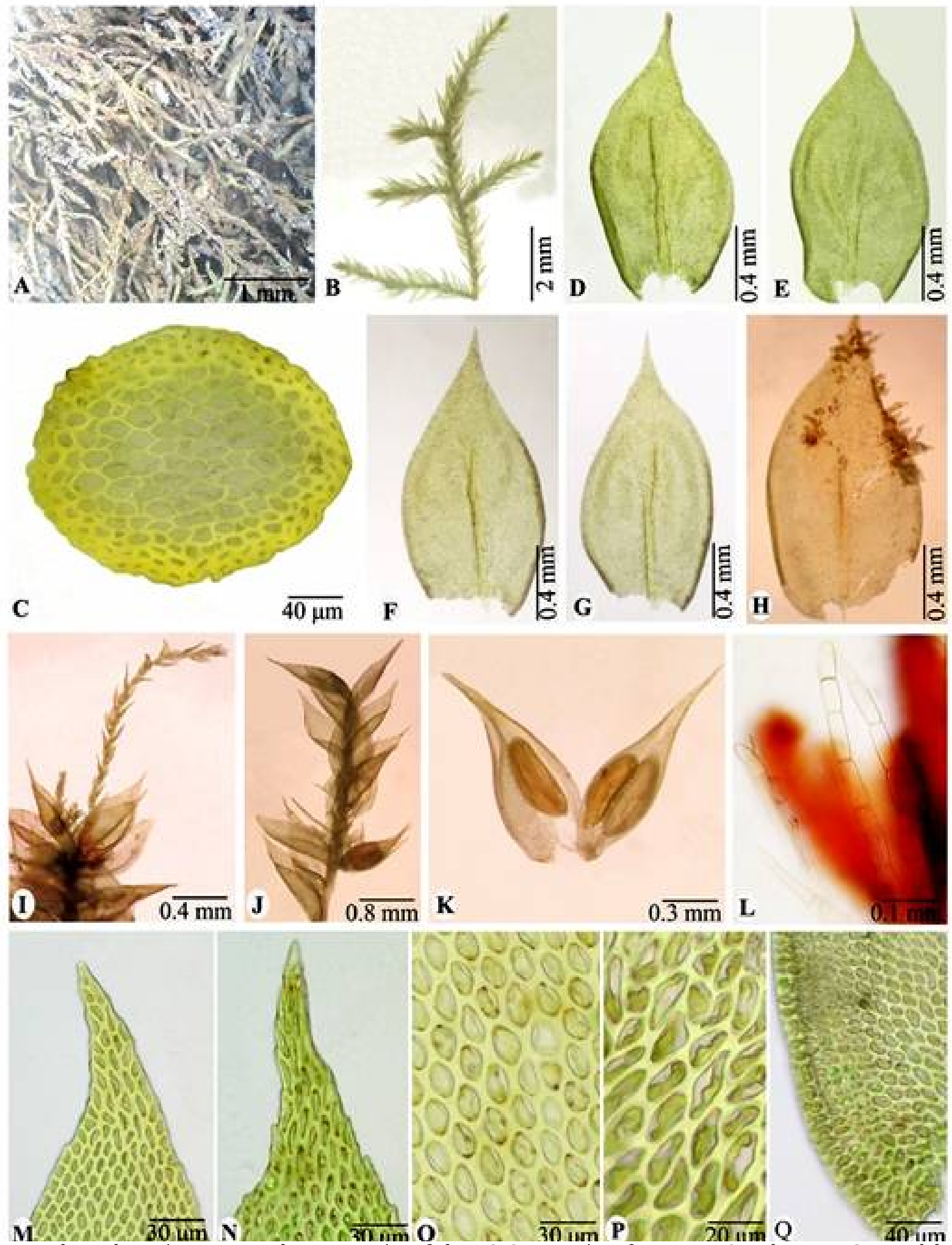

Fig 1. Regmatodon orthostegius Mont. A. Plants B. Portion of plant C. Cross section of stem D-E. Stem leaves F-G. Branch leaves H. Branch leaf with gemmae I. Gemmae growing into plantlets J. Perigonium K. Perigonial leaves with antheridia L. Paraphyses $\mathbf{M}-\mathbf{N}$. Leaf apical cells $\mathbf{O}$. Leaf median cells $\mathbf{P}$. Leaf basal cells $\mathbf{Q}$. Leaf basal cells at margin

Moss.: 116. 2005; Manju \& al., Trop. Bryol. Res. Rep. 7: 17. 2008; A.E.D. Daniels, Arch. Bryol. 65: 82. 2010; A.E.D. Daniels \& al., Bryofl. Indira Gandhi Natl. Pk.: 269. 2018. - Type: India (Tamil Nadu), Nilgris, corticolous on a shrub, around Kaitie (Ketti), Perrottet s.n. (PC). Anhymenium polycarpon Griff., Calcutta J. Nat. Hist. 3: 275. 1843. A. polysetum Griff., Not. Pl. Asiat. 2: 472. 1849. Regmatodon polycarpus (Griff.) Mitt., J. Proc. Linn. Soc., Bot. 1 (Suppl.): 127. 1859; D.A. Eakin, Nova
Hedwigia 67: 144. 1998. R. polysetus (Griff.) Thér., Bull. Soc. Bot. Genève Sér. 2, 26: 88. 1936. (Fig. 1)

Plants caespitose, glossy, yellow-green. Main stems creeping, $2-3 \mathrm{~cm}$ long, $0.19-0.2 \times 0.15-0.18$ $\mathrm{mm}$ in cross section, ovate, with a central strand; cortex 3- or 4-layered; cells 6-16 $\times 4-8 \mathrm{~mm}$, thickwalled; medullary ones $12-28 \times 8-22 \mathrm{~mm}$, thinwalled; branches pinnate. Leaves imbricate, 
erectopatent, irregularly inrolled at margin; stem leaves $0.8-1.4 \times 0.3-0.8 \mathrm{~mm}$, ovate, concave, smooth at apical margin, apiculate; branch leaves $0.8-1 \times$ 0.3-0.5 mm, ovate, concave, smooth or faintly toothed at apical margin, apiculate; cells irregularly elliptic-rectangular, smooth; apical cells 12-28 $\times 4-8$ $\mu \mathrm{m}$; median ones $4-16 \times 3-8 \mu \mathrm{m}$; basal ones $8-28 \times$ 4-12 $\mu \mathrm{m}$, subrectangular to quadrate; extreme basal ones, $12-24 \times 10-16 \mu \mathrm{m}$, more rectangular; costa single, more than half as long as leaf. Perigonia bud-like; perigonial leaves lanceolate, narrowing into a long, acuminate apex, 0.8-1 × 0.4-0.6 mm, inrolled and smooth at margin, concave, ecostate. Antheridia 0.4-0.6 × 0.15-0.18 mm, sausage-shaped, stalked; paraphyses $0.5-0.7 \times 0.012-0.014 \mathrm{~mm}$, filiform. Sporophyte not seen.

Habitat: Corticolous on Artocarpus heterophyllus Lam. (Moraceae), the jack tree, in degraded evergreen forests, ca $1400 \mathrm{~m}$.

Distribution: Africa, North \& South America, Bioko Island (Fernando Po), China, Madagascar (Malagasy), Papua New Guinea, South \& Southeast Asia and India: Central India, Himalaya, Northeast India, Western Ghats $(1,3,6)$ and Eastern Ghats of Tamil Nadu (Salem). Fairly common.

Specimens examined: Eastern Ghats: Tamil Nadu, Salem Dist., Sherveroy Hills, Yercaud, ca 1400 m, 10.08.2015, A.E.D. Daniels \& P.M. Biju 960 p.p., 961 (SCCN).

\section{Discussion}

According to Eakin (1), Regmatodon declinatus is so closely allied to $R$. orthostegius, it is almost impossible to segregate the plants if they are collected in their vegetative phase as distinct morphological characters of the gametophore are hardly found. Nevertheless, the leaves of $R$. declinatus are distinctly longer and narrower than those of the latter and this character is found to be consistent. Based on this feature, the material to hand has been best identified as $R$. orthostegius.

\section{Authors' contribution}

AEDD - Collection, determination and preparation of the MS; PMB - Collection, dissection and help in determination; VA - Dissection and preparation of photographic plates.

\section{Acknowledgements}

The authors thank the Tamil Nadu State Forest Department for permission to explore the study area and help in the field, the Ministry of Environment, Forests \& Climate Change, Govt. of India, New Delhi, for financial assistance, and the Principal, Scott Christian College, for providing facilities.

\section{Conflict of interest}

The authors declare that they have no competing interests

\section{References}

1. Eakin DA. A taxonomic revision of the moss genus Regmatodon. Nova Hedwigia 1998; 67: 139-52.

2. Eakin DA, Allen B. A nomenclatural note on Regmatodon. Nova Hedwigia 1999; 69: 311-12.

3. Gangulee HC. Mosses of Eastern India and adjacent regions. III(Fasc. 7). Calcutta; 1978. P.1547-2145.

4. Vohra J.N. Hypnobryales suborder Leskeineae (Musci) of the Himalayas. Rec. Bot. Surv. India 1983; 23: 1-336.

5. Lal J. A checklist of Indian mosses. Dehra Dun: Bishen Singh Mahendra Pal Singh; 2005.P. 1-164.

6. Daniels AED, Sreebha R, Kariyappa KC. Bryoflora of Indira Gandhi National Park in Anamalai Hills, India. Dehra Dun: Bishen Singh Mahendra Pal Singh; 2018. P. 1-513.

7. Kumar GV, Krishnamurthy KV. Moss flora of Shervaroy Hills of Eastern Ghats (South India). In: Nath V, Asthana AK, Editors. Current Trends in Bryology. Dehra Dun: Bishen Singh Mahendra Pal Singh; 2007. p. 227-43.

8. Palani R, Sathish SS, Thamizharasi T, Vijayakanth P. Checklist of Mosses (Bryophyta) of Bodamalai Hills in Eastern Ghats, Tamil Nadu. Pl. Sci. Today 2017; 4: 49-54. https://doi.org/10.14719/pst.2017.4.1.278

9. Sathish SS, Thamizharasi T, Palani R, Vijayakanth P, Vimala A. Checklist of mosses (Bryopsida) of the Kalrayan Hills in the Eastern Ghats of Tamil Nadu, India. Eng. Biosci. 2014; 2: 28-33. 